REVISTA CHILENA DE LITERATURA

Noviembre 2008, Número 73, $81-108$

\title{
TEMBLORES DE ARTERIAS Y CÁRCELES DE FUEGO: LITERATURA EN EL BRASIL COLONIAL ${ }^{1}$
}

\author{
Clicie Nunes \\ Universidad de Concepción \\ cnunes@udec.cl \\ RESUMEN / ABSTRACT
}

El relato Cultura e Opulência do Brasil por sus Drogas e Minas de André João Antonil describe los procesos de la producción colonial portuguesa en América. El texto publicado en Lisboa en 1711 contiene informaciones objetivas y prácticas, que se exponen metamorfoseadas por la influencia del barroco literario. El narrador transita entre la descripción realista y la subjetividad barroca; se puede percibir el carácter lúdico de sus prédicas moralizadoras a través de metáforas a veces exacerbadas del universo del ingenio de azúcar. En la colonia portuguesa, la identidad negra ha sido transfigurada y la formación de una conciencia colonial surge en discursos que se instalan en la memoria social. En su texto, el padre Antonil elabora determinados valores que transforman su obra en un discurso "barroco-apologético" en torno al universo colonial: "Brasil es infierno de negros, purgatorio de blancos y paraíso de mulatos y mulatas".

PALABRAS ClAVE: Brasil, barroco, literatura, azúcar, esclavos.

The narrative Cultura e Opulência do Brasil por sus Drogas e Minas by Father André João Antonil, describes the processes of the colonial Portuguese production in America. The text, published in Lisbon in 1711, contains both objective and practical information, transformed and influenced by 'literary baroque'. The narrator wanders from realistic transcription to

1 Este artículo es parte de la investigación El valiente y el caníbal en la literatura colonial latinoamericana: una proyección hacia la mundialización, proyecto Fondecyt 3030040 - Postdoctorado 2003. 
baroque subjectivity, and we may perceive a playful character in his morality sermons, as he sometimes uses extreme metaphors belonging to the sugar mill scene. In the Portuguese colony, the black identity has been transfigured and the formation of a colonial conscience arises in speeches that have taken roots in a collective memory. Father Antonil elaborates those values which help to transform his work into a 'baroque-apologetic'speech about the colonial world: "Brazil is the hell of blacks, the purgatory of whites and the paradise of mulatto men and women".

KEY WORDS: Brasil, Baroque, Literature, Sugar mill, slaves.

Atrás um cego, um negro, um mamaluco,

Três lotes de rapazes gritadores:

É a procissão de cinza em Pernambuco

Gregorio de Matos

El paisaje de la colonia portuguesa en América y su representación en la literatura se revela en la composición de imágenes sostenidas en abundancias y riquezas. Sol, floresta, clima cálido y afectuoso, imágenes de la creación mítica de la humanidad, estímulos para la imaginación y sus sentidos. El espacio colonial brasileño representa, de ese modo, un universo propicio al desarrollo de una literatura diversa, temática y formal: “[...] la inteligencia brasileña, buscó en las raíces de la tierra y del nativo imágenes para afirmarse frente al extranjero: entonces los cronistas volvieron a ser leídos, y hasta glosados, tanto por el Alencar romántico y saudosista como por Mário de Andrade o Oswald de Andrade vanguardistas" (Bosi 16). Sin embargo, una característica del período colonial brasileño es la presencia de la estética del Barroco como expresión simbólica del universo colonial.

A través de la literatura y de la arquitectura, el Barroco ha traducido el espíritu del mestizaje en que la figura del esclavo negro africano "penetra sinuosamente el receso doméstico, actuando como disolvente de cualquier idea de separación de castas o razas, de cualquier disciplina fundada en tal separación" (Buarque de Holanda 55). La obra satírica, amorosa y religiosa de Gregorio de Matos, poeta baiano del siglo XVII, y el relato de André João Antonil, del siglo XVIII, padre italiano y atento observador de la cultura y las opulencias de Brasil, son ejemplares. Mientras los poemas de Gregorio de Matos traducen una realidad específica, doblada en sí misma, el padre Antonil elabora un texto revelador de valores que transforman su obra en un discurso barroco-apologético del universo colonial: "Brasil es infierno de negros, purgatorio de blancos y paraíso de mulatos y mulatas", divulgando 
informaciones que transformarían a Brasil en un espacio generador de posibilidades: "por tanto, con esta limitada oferta provoco aquella generosa liberalidad, que no consiente ser rogada, por no parecer que, dando, quiera vender beneficios" (Aos senhores de engenhos e lavradores do açúcar e do tabaco e aos que se ocupam em tirar ouro das minas do Estado do Brasil en: Antonil, Cultura e opulencia).

\section{LA CIVILIZACIÓN DEL AZÚCAR}

Los poemas de Gregorio de Matos y el relato Cultura e opulencia do Bra$\mathrm{sil}^{2}$ forman parte de los textos que otorgan a la "civilización del azúcar" un lugar importante en la cultura brasileña que se actualiza principalmente en el ensayo sociológico del siglo XX, Casa Grande e Senzala, de Gilberto Freyre. La plantación de la caña de azúcar funciona, en el estudio de Freyre, como escenario para la formación de la cultura brasileña. En Casa Grande e Senzala, publicado en Brasil en 1933, Gilberto Freyre fortalece una visión de mundo en que las relaciones sociales y culturales están fundamentadas en un sistema agrario y patriarcal que invade la vida doméstica y sexual, los negocios y la religiosidad, al mismo tiempo en que entrelaza azúcar y trópico. La obra considera que la presencia africana en Brasil, aunque en su condición de pueblo esclavizado, ha proporcionado a la formación cultural brasileña una suerte de privilegio, ya que el proceso del mestizaje alcanzaría su plenitud en una convivencia social generosa: "a Gilberto le debemos, sobre todo, el haber aprendido a reconocer en la cara de cada uno de nosotros o en la de nuestros tíos y primos -si no con orgullo, al manos con tranquilidad-, una bocaza carnosa, cabellos ensortijados o esas fornidas narizotas de indiscutible procedencia africana y servil" (4). De ese modo, la cultura azucarera es el ámbito primero en el cual se desarrolla la instalación de los pueblos africanos en Brasil, además de ser la actividad con la que se inicia el gran desplazamiento migratorio de esclavos bajo la forma del tráfico que el sistema colonial instala, promueve y adopta por más de tres siglos.

La introducción de los africanos esclavizados y sus descendientes junto a otras culturas compuestas por inmigrantes de diversa índole, personas en

2 Las citas y referencias a estas obras en español son traducciones mías. A partir de este momento, utilizaré solamente Cultura e opulencia para referirme a la obra de Antonil. 
tránsito o pueblos locales, ha creado un paisaje étnico que se constituye como un espacio múltiple, generador de prácticas y de sistemas de conocimientos, en que grupos de personas de diferentes orígenes de África han tenido que reinventarse en América. Entre estas reinvenciones en las relaciones con el nuevo universo cultural, se encuentra la construcción religiosa mediatizada y sincrética y la formación de nuevas identidades surgidas de alianzas de aproximación étnica, social y política. El contexto esclavista que contiene estas reorganizaciones de identidad son percibidas por Antonil:

Negarles totalmente sus juegos, que son el único alivio de su cautiverio, es quererlos desconsolados y melancólicos, de poca vida y salud. Por tanto, no les extrañen los señores el crear sus reyes, cantar y bailar por algunas horas honestamente, en algunos días del año, y el alegrarse inocentemente en la tarde después de haber hecho por la mañana sus fiestas de Nuestra Señora del Rosario, de San Benedicto y del orago de la capilla del ingenio (I- IX).

África se reescribe en América a través de las nuevas formas adoptadas por las antiguas sociedades que en el territorio africano han tradicionalmente controlado las relaciones de comercio y guerra, de dinámicas naturales de conquistas territoriales, incluyendo el cambio de esclavos y de mercancías. Desde la perspectiva del colonizador, en el proceso de inventar un espacio diverso, se originan las representaciones del Otro colectivo: moros, gentíos, degradados, esclavos.

De ese modo, la condición misma del esclavo ha forzado a la población africana en América a reagruparse étnicamente, creando naciones que se mantienen alrededor de sus actividades, ya sean de carácter social, como es el caso de las hermandades, o a través de los cultos a los orishas, muchas veces acompañados por blancos cristianos y por padres católicos en la colonia.

La redefinición y adaptación del cautivo en América es primordialmente un producto del esfuerzo europeo de transformar al africano capturado en esclavo. Para ese fin, se hizo necesario desconstruirlo como sujeto importante en su medio para volver a integrarlo socialmente, de esta vez como parte del sistema esclavista colonial. Obligados a renunciar a su lengua, espacio, religión, prácticas sociales y culturales, como son la danza, música y medicina, los africanos han tenido que enfrentarse a la traumática diferenciación corporal. Los cambios en el cuerpo de hombres y mujeres de África son señales que se imponen en el cuerpo capturado que se resignifica: las marcas en su piel ya no son cicatrices, tatuajes, esculturas corporales provocadas por el 
uso prolongado y continuo de adornos específicos para este fin, o el rediseño de los dientes y de los peinados, las pinturas que marcan las jerarquías y las posiciones sociales ${ }^{3}$. La interferencia en la piel y en el cuerpo del africano a través de las marcas de pertenencia del amo o de los castigos es una interferencia en su implícito cultural, en aquellos valores que sistemáticamente son utilizados como regla social mínima: "los valores somáticos constituyen una de las determinantes de las sociedades occidentales; podemos encontrarlos en Las políticas de Aristóteles, y podemos sobre todo identificar en mediados del siglo XV, en Gomes Eanes de Zurara, una de los primeros intentos de organizar la relación entre blancos y no blancos" (Castro Henriques 65).

Uno de los instrumentos utilizados para la adaptación obligada del negro africano como esclavo en territorio colonial portugués es la recurrencia a un sincretismo religioso, forma de metafísica mestiza que, en la visión de Roger Bastide, también es "la influencia de las mujeres negras sobre los pequeños portugueses, el abismo cavado entre los colores y las civilizaciones, aproximando razas y entrelazando culturas" (55).

Como parte del trabajo de "administrar diversidades", los colonizadores crean formas diferenciadas, según la región y el período, para clasificar a los africanos que son trasladados entre las colonias. A pesar de los esfuerzos empleados para evitar las aproximaciones étnicas por afinidades ancestrales, la unión de diferentes pueblos africanos en América se realiza en la manutención de un sentimiento religioso, en la permanencia de ceremonias coloniales específicas, como la coronación de los reyes negros, en el interior de los quilombos o de las hermandades católicas. Sin embargo, según la historiadora Marina de Mello e Souza, las celebraciones de la coronación de los reyes del Congo en Brasil en el siglo XVII podrían tanto representar una legítima continuidad de la cultura africana como su transformación:

3 Ocurre, por lo tanto, un desplazamiento de significado, semejante a lo que ocurre entre los amerindios, cuando sus artefactos corporales y sagrados son llevados hacia Europa para exhibición o para completar algún gabinete de curiosidades: "la curiosidad, en la medida en que los espacios se van desvelando, la sed de conocimiento que aumenta en la misma proporción y el imaginario occidental, requieren, cada vez más, nuevas relaciones. La curiosidad como motor de la ciencia, las rarezas naturales, arqueológicas, artísticas, todo se torna objeto del deseo renacentista. Después del descubrimiento de América, las colecciones y los gabinetes de curiosidades se multiplican" (Nunes 131). 
Mientras para unos las fiestas alrededor de los reyes remitían a los jefes africanos, a rituales de iniciación, a la prestación de fidelidades, para otros ellas se asociaban a la noción de un imperio, que se extendía por los cuatro cantos del mundo: Europa, África, América y Asia, y que tenía la experiencia de la catequesis en la región del antiguo reino del Congo como de momentos emblemáticos del empeño evangelizador de Portugal (127).

A su vez, las ceremonias y rituales de los cultos africanos en Brasil han sido configurados como expresiones religiosas relacionadas con un universo mágico a través de procedimientos como la utilización de la sangre de animales sacrificados, el movimiento de las danzas o el ritmo del tambor intrínseco a las deidades, o por la "incorporación" misma, indiscutible presencia del cuerpo del individuo como expresión de lo sagrado. La ceremonia ritual africana en Brasil "tiene la finalidad de llamar, a través del tambor, de los cantos en lengua fon o nagô, de la música al fin, el dios africano, con el objetivo de que 'monte su caballo'" (Bastide 73). La práctica del candomblé en el territorio americano portugués se intensifica, por lo tanto, como factor de afirmación de la africanidad, trasmutada en ceremonia de participación controlada y colectiva. Instalado en la hacienda colonial productora de azúcar, el ritual religioso es incorporado a la cultura americana-portuguesa como un elemento fundamental en la organización del sincretismo. Según Roger Bastide, los dioses africanos en Brasil se encuentran con los santos católicos, formando correspondencias:

Oxalá es Jesús, Xangô es São Jerônimo, Omulu es São Lázaro... el ritual final de las ceremonias africanas de iniciación obliga la asistencia a la misa católica a los que se están iniciando. Y en todo santuario de culto existe, al lado del peji africano, con piedras rociadas de sangre y platos de alimentos, un altar católico con imágenes de santos en la cima. El catolicismo, entretanto, es solo una fina capa que cubre África simple máscara blanca sobre el rostro negro (74).

Más allá de las expresiones religiosas como elemento de unión y una forma de reinventarse en el esclavismo, los africanos conservan en el arte la unión con sus esencias. La existencia de un catolicismo negro ha generado un nuevo paisaje en que los esclavos o negros libres ocupan las calles con "desfiles, cantos, danzas y representaciones toleradas y a veces apreciadas por los señores, por los blancos, por los pardos emblanquecidos por el ascenso social" (Mello e Souza 86). Durante las fiestas católicas, por lo tanto, el 
orden colonial se transforma para dar lugar a una ruptura en el cotidiano de la relación señor-esclavo, en que el negro puede ocupar un lugar de liderazgo en la sociedad esclavista. Partícipes del juego, los amos y sus familias asisten participando de la representación, algunos llegan a prestar sus joyas y ropas, como en una farsa:

Luego de asistir a la misa alrededor de 400 hombres y mujeres eligieron un rey y una reina, y marcharon por las calles cantando, bailando y recitando los versos hechos por ellos, acompañados de oboes, trompetas y tambores vascos. Estaban vestidos con las ropas de sus señores y señoras, con cadenas de oro y aros de oro y perlas, algunos de ellos enmascarados. Todas las entretenciones de esta ceremonia les costaron 100 escudos. El rey y sus oficiales no hicieron nada en toda esta semana, además de andar solemnemente, con la espada y la daga a su lado (Urbain Souchu Rennefort, Histoire des Indes Orientales. Paris: Arnoul Seneuze, 1688. Citado por Marina Mello e Souza 88).

Esos momentos de libertad y poder del negro en Brasil preocupan, sin embargo, a algunos propietarios de esclavos que temen posibles rebeliones, impulsadas por el sistema esclavista y sus relaciones de poder:

Los señores de esclavos habían creado un sistema de terror masificado y permanente que obedecía al doble propósito de juzgar rebeldías y asegurar el normal funcionamiento de la organización económica. Los castigos y los tormentos infligidos a los esclavos no constituían actos aislados de puro sadismo de los amos y de sus capataces, sino una necesidad impuesta irrechazablemente por la orden esclavista misma, que de otro modo entraría en colapso. Pues, sin la compulsión del terror, el individuo simplemente no trabajaría ni se sometería al cautiverio (24).

En el siglo XVIII el jesuita italiano Jorge Benci (Economia cristã dos senhores no governo dos escravos) y João Antonil (Cultura e opulencia do Brasil por sus drogas e minas), han escrito obras de fundamental importancia para el entendimiento de la función que el esclavo y su propietario ocupan en el universo colonial brasileño. Benci escribe, en 1700, una pedagogía cristiana para la educación del negro, con el objetivo de optimizar la producción comercial de la colonia, adaptar el esclavo a su "destino" de servir y obedecer y otra pedagogía en que propone al propietario una educación del esclavo "enérgica y moderada": "Si se enseña una sola vez, no habrá de aprovechar, 
ni hacer fruto, pero enseñándole y volviendo a explicar, entonces florecerá y hará provecho, aun en las piedras más duras, o sea, en las almas más rudas" (95).

A su vez, Antonil refiere a la imperfección cuando discursa sobre la cristianización de los esclavos cuya culpa la tiene los amos y propietarios de ingenios: "son tan poco cuidadosos de lo que pertenece a la salvación de sus esclavos, que los tienen por mucho tiempo en el cañaveral o en el ingenio, sin bautismo; y de los bautizados, muchos no saben quién es su Creador, lo que habrán de creer [...]" (I - IX). Estas contradicciones pueblan las páginas de los textos sobre la esclavitud, comprendida sutilmente como un "mal necesario". Los religiosos que han escrito sobre el sistema esclavista en América siempre se han debatido entre el deber que poseen como representantes del catolicismo metropolitano en América, y la realidad que se traduce en la máxima "sin esclavos no hay colonia", ampliamente divulgada en los siglos coloniales.

La obra Cultura e opulencia do Brasil por suas drogas e minas ${ }^{4}$, del jesuita italiano André João Antonil, publicada en Lisboa en 1711, describe el cultivo, la elaboración y el comercio de los productos de la colonia portuguesa en América, refiriendo sus distintas partes y calidades. En su totalidad, está compuesta por cuatro partes independientes: la primera consta de tres libros, cada uno con doce capítulos, dedicados a los procesos de la plantación de la caña de azúcar y su fabricación; en la segunda parte del libro, Antonil se refiere al cultivo del tabaco; la tercera relata la explotación de oro en Brasil y la última parte aborda la creación de ganado y la fabricación de cuero. No obstante que el descubrimiento y la explotación de oro en Minas Gerais son fundamentales en el siglo XVIII para la manutención del sistema colonial, Antonil reserva un importante espacio en Cultura e opulencia para la producción del azúcar. Dedica a esta actividad económica más de la mitad del libro, en que relata y describe todos los procesos que involucran la adquisición de un ingenio

4 Para este artículo, usaré la forma abreviada del título: Cultura e opulencia. Además, las citas en español de las ediciones en portugués son traducciones mías. 
$r a^{5}$, categoría en que se inscribe el Sergipe do Conde, en el Recóncavo Baiano, ingenio que lo abriga en su investigación. La experiencia de Antonil en el Sergipe do Conde ha derivado en la descripción cuidadosa de diversos aspectos de la vida cotidiana en una hacienda productiva. El espacio del ingenio es entonces, un universo cerrado donde las relaciones de productividad y del entramado social público y privado reflejan las formas de contacto personales en el siglo XVIII. La dedicación de un número mayor de páginas a la producción de azúcar en el texto de Cultura e opulencia muestra la preocupación del autor por narrar en detalles no solo el lucro y las ganancias de la cultura azucarera, como su contexto, generando un acervo importante para la cultura brasileña, en lo que concierne las referencias a la práctica íntima familiar en el ingenio. Basado en la construcción de una red de relaciones establecida a lo largo de aproximadamente dos siglos, Antonil logra montar un retrato de la vida cotidiana en un Brasil movilizado por la coexistencia de vibrantes antagonismos como el convivir diario entre la capilla y el pelourinho, en el "beneficio de se blanquear, sin el perjuicio de se derretir, sino cuando basta para perfectamente se purgar /.../ ejercicio de las virtudes, que están en el medio de dos extremos viciosos" (II-XII).

Por su contenido, el libro ha sido censurado por la administración colonial y, "por la rareza extrema de su edición príncipe sobre todo, pleno de grandes méritos por la abundancia, riqueza y sinceridad de los informes" (2). Mientras escribe sobre las etapas del proceso de la fabricación del azúcar, enseña y aconseja a quienes quieran tornarse propietarios de los ingenios reales el mejor procedimiento en el tratamiento con los esclavos y el personal administrativo de la hacienda, como tratar a los huéspedes y vecinos, la manutención de la jerarquía en el núcleo familiar, así como la comercialización y distribución del azúcar. Las partes II, III y IV están dedicadas a la labranza del oro, a los cultivos de tabaco y la creación del ganado. El texto describe desde el proceso de la plantación,

Según Antonil, "de los ingenios, unos se llaman reales, otros, inferiores, vulgarmente engenhocas. Los reales ganaron este apodo por tener todas las partes de que se componen y de todos los talleres, perfectos, llenos de grande número de esclavos, con muchos cañaverales propios y otros obligados a la molienda; etc." (Proemio). 
corte y manufactura, hasta los preparativos de embarque y el viaje de los navíos abastecidos de productos en la colonia. La publicación temprana de Cultura e opulencia habría revelado todo el sistema económico, administrativo y social del Brasil en un momento clave de su establecimiento como territorio generador de riquezas. Entretanto, Antonil también se interesa por la actividad de la extracción del oro justo en el momento de su hallazgo: "y han sido estos capítulos, creemos, la principal causa de la destrucción de su obra por el gobierno portugués" (Taunay 3$)^{6}$.

En el estudio preliminar de Affonso D'Escragnolle Taunay, publicado en 15 de junio de 1922, es notable la preocupación con la originalidad del texto: "no sólo escribió Antonil un manual del agricultor de la preciosa gramínea [caña de azúcar] que fue la base de la riqueza nacional, hasta mediados del siglo XIX, como aun un código de criterio y de buen tono, modelo de provecho en aquellas épocas atrasadas" (Introducción). Luego del análisis de las partes del libro que contienen las informaciones necesarias que parecen justificar su censura y aprensión, Taunay señala que Antonil utiliza un lenguaje coloquial, profundamente inserto en el universo popular de la colonia, en el arte de la industria y del comercio de sus riquezas, "un estilo de hablar claro y coloquial, que se usa en los ingenios" (11). El estilo de Antonil, por lo tanto, es reflejo de una sociedad

6 Cultura e opulencia do Brasil por suas drogas e minas ha sido revisado y aprobado por la censura inquisitorial un año antes de su publicación. Sin embargo, "mal saira, ou talvez nem saira o livro da casa do impressor quando, sobre a edição, se abateram inexoráveis o veto e o seqüestro régio. Foi confiscada e com tal severidade destruída, que dela apenas escaparam três ou quatro volumes, como demonstração do inflexível princípio grandioso de que ninguém mata as idéias" (Taunay 8). Entretanto, diversas tesis sobre la prohibición del libro han sido planteadas: aproximación a los modos de gobernar "según los principios de Maquiavel", estímulo a los propietarios de tierra al enfrentamiento con la metrópoli por el poder económico, revelación de secretos industriales relativos a la producción de azúcar, exposición del potencial de la colonia portuguesa y la posible ruptura con la política de Portugal, resultado de un conflicto entre el Estado y la Iglesia por el privilegio a la censura, la conversión del libro de Antonil en un "mapa da la mina", en una analogía con la parte dedicada a la extracción del oro, en que el autor revela claramente el camino hacia las minas (Dimas 144). 
que empieza a dibujarse en el escenario colonial y que se plasma en la diversidad $^{7}$.

\section{MESTIZAJE, BARROCO Y ARTE EN EL BRASIL COLONIAL}

En el universo donde las calles y las iglesias abrigan la estética barroca, un sentido religioso se asoma. Santuarios de blancos y de negros, grandes fiestas profanas, la situación de los padres de la iglesia frente a la práctica de la esclavitud se refleja en la manifestación artístico-cultural del Barroco en Brasil. Producidos principalmente en el siglo XVII, su rasgo principal es la tensión entre espíritu y materia, cielo y tierra, razón y emoción, contención y desbordamiento, cientificismo y religiosidad. Si en Europa el Barroco surge en medio del conflicto entre protestantes y católicos, en Brasil su estética se desparrama sobre las tensiones de un territorio diverso, mestizo y sincrético: "angelitos trazan guirlandas de sonrisas alrededor de los altares, ostentando, de uno y de otro lado de las naves, la bonhomía del rostro redondo, de ojos azules color del mar, de los cabellos revueltos en caracoles. Pero, el misticismo se afirma como vencedor" (Bastide 60). De ese modo, la complejidad y las contradicciones de la estética barroca se juntan en el universo colonial brasileño, territorio de tensiones y exuberancias. Tensión entre espíritu y materia, cielo y tierra, razón y emoción, contención y desbordamiento, cientificismo y religiosidad ${ }^{8}$. Las bases de la cultura brasileña en el período colonial han sido creadas a partir del mestizaje, a través del juego

7 El texto se inscribe en el llamado "Barroco brasileño", estilo que vigora en Brasil durante los siglos XVII y XVIII. Los poetas Gregorio de Matos, Botelho de Oliveira, Frei Itaparica y las primeras Academias "respiran motivos y formas del barroquismo ibérico e italiano" (Bosi 49). Entretanto, en la segunda mitad del siglo XVIII, la explotación regular del oro impulsa, como sustrato, la arquitectura, la escultura y la música. Las obras literarias de la segunda mitad del siglo XVIII pertenecen a una suerte de "barroco tardío" que se establece en base a una diacronía en relación con sus contemporáneos, cuya poesía “ya no es, sino residualmente, barroca sino rococó, arcádica y neoclásica” (Bosi 39). En lo que concierne a la narrativa, la figura del padre jesuita Antonio Vieira es ejemplar. La prosa de Vieira es un discurso religioso que llama a la acción. Ofensivo y defensivo a la vez, se inscribe en la participación del autor como sujeto activo de los procesos administrativos, religiosos y económicos de la colonia portuguesa, pero también como un celoso defensor de los derechos de los portugueses contra las invasiones holandesas en el siglo XVII en Brasil.

8 Además de la literatura, el Barroco en Brasil solo alcanzaría su punto máximo en la segunda mitad del siglo XVIII. En ese período, durante el ciclo del oro en Minas Gerais, la 
entre oposiciones y contrarios. Las diferencias culturales presentes y contemporáneas en la colonia portuguesa en América han creado una importante sustentación que se amalgama en el mestizaje. Esta argumentación sugiere que la vida cotidiana en el período colonial brasileño ha sido un exhaustivo juego de paradojas. Sin embargo, las obras escritas en este período cultivan imágenes que se refieren a la idea de Brasil como un espacio de generosidades y abundancias, un paraíso terrenal, figuración que se disuelve en las narrativas sobre el cautiverio africano, así como en la instalación colonial como máquina o parte intrínseca de una maquinaria mayor, inscrita en los espacios de sociabilidad "de hecho, la literatura brasileña emerge de la literatura occidental del Barroquismo [...] no solo como un estilo de arte, sino como un composición cultural" (Coutinho 79-80).

En lo que concierne a la literatura producida en los siglos XVIIXVIII, clasificarla como un arte puramente barroco sería generalizar, ya que otras tendencias han compartido el territorio colonial. Según Afranio Coutinho, la literatura producida sobre Brasil en los siglos XVI y XVII ha impulsado las literaturas posteriores escritas "bajo ropaje literario" (78). De ese modo, la tendencia al elogio de la tierra, presente en los textos coloniales, genera el mito del ufanismo que "construirá una línea permanente de la literatura brasileña de prosa y verso. Pero Vaz de Caminha /.../ Itaparica, Nuno Marques Pareira, son ejemplos de la serie de cantores de la 'cultura e opulência', o autores de los "diálogos das grandezas" que constituyen esa singular literatura de catálogo y exaltación de los recursos de la tierra prometida" (79). No obstante, Coutinho señala que el estilo del Barroco literario "impregna" profundamente los escritores de la época, como el historiador Frei Vicente do Salvador. La expresión barroca transita, simultáneamente, en la epopeya, en el diálogo y en la poesía lírica, marcada por una fuerte presencia de los aspectos mitológicos que se mezclan en la descripción, las formas alegóricas que conviven con la visión realista. Además, está el texto narrativo que incorpora aspectos psicológicos, la presencia de una humanidad que se expresa como guerrera junto a temas de la poesía

arquitectura, la escultura y la vida musical se desarrollaron hasta el punto de constituirse en un Barroco "minero". 
pastoral, drama y poesía, el sentimiento solemne y el burlesco, todos considerados bajo el mestizaje lingüístico, que se inicia en las obras de evangelización, y de nuevos sentidos que tendrán por resultado el estilo brasileño diferenciado (80).

El Barroco literario como expresión múltiple interactúa con otros estilos, amalgamando originalidad con tradición, "en una época en casi todo alrededor era pigmeo, las letras brasileñas, por su voz, ya hablan por sí mismas, con la originalidad mestiza, a lo que el barroquismo prestó toda suerte de artificios y medios de realización eficiente" (Candido 87). Antonio Candido, en Literatura e sociedade considera que las manifestaciones literarias o de tipo literario hasta el siglo XVIII en Brasil se encuentran "bajo el signo de la religión y de la transfiguración” (91). Según el crítico, la religión ha sido la referencia y la ideología que ha regido la cultura colonial brasileña, como idea y principio político, forma de vida y patrón administrativo: "no es sorpresivo que fuese, igualmente, principio estético y filosófico" (92). Además de la literatura histórica, el crítico brasileño destaca la presencia de la oratoria sagrada, cuyo mayor representante es el padre Antonio Vieira, en que "la religión-doctrina se mezcla indisolublemente con la religión-símbolo. Estamos en pleno espacio barroco, y la dialéctica intelectual esposa las formas, las metáforas, toda la marcha en arabesco de la expresión culta" (92).

En ese sentido, el poeta Gregorio de Matos es, según Antonio Candido, el símbolo de lo profano que irrumpe en la religiosidad de la colonia como un poeta que rescata la oralidad del pueblo de Bahia, mezclada con un humor satírico e hiriente, carnalmente exuberante, religiosamente obsesionado con la muerte. No obstante, ha existido una suerte de "Barroco vacío y malabarístico", cuyo maravillamento por la tierra lleva a una hiberbolización literaria y artística, que se extiende en Brasil por casi dos siglos, transfigurando la realidad (93). Sobre la escritura real y objetiva de algunos cronistas brota una visión que presta a la tierra un estatus de leyenda y rasgos maravillosos:

Recordemos solamente el caso del mundo vegetal, primero descrito, después retocado, finalmente alzado a la metáfora. Si en Gabriel Soares de Souza (1587) la piña es fruta, en las Notícias curiosas e necessárias das cousas do Brasil (1668), de Simão de Vasconcelos, es fruta real, coronada y soberana; y en las Frutas do Brasil (1702), 
de Frei Antônio do Rosário, la alegoría se eleva al simbolismo moral, pues la regia pulpa es dulce a las lenguas sanas, pero mortifica las machucadas -o sea, galardona la virtud y castiga el pecado (Candido 94).

La existencia del arte barroco en algunos países europeos está intrínsecamente ligado al catolicismo, como expresión de una espiritualidad en que los santos son hombres ejemplares y guerreros despiadados, lo que hace de esta estética una creación abstracta, al mismo tiempo que concreta y material, resultando en un arte que privilegia los sentidos y que puede entender el pensamiento racional como parte del universo de los sentidos. En ese sentido, la estética barroca en la colonia americana sería una feliz adaptación a la creación de una cultura que se construye bajo los signos de una paradoja, simultáneamente a las fuerzas del mestizaje. Estéticamente, el Barroco presenta formas complejas que apelan a los sentidos del receptor, ya sea las manifestaciones de un arte que es sensual porque material, creativo y pleno. No obstante, conviven en el territorio del Brasil colonial la prédica del padre Antonio Vieira. Los sermones de Vieira son ideas en juego, en medio de un discurso que pretende organizarse de modo persuasivo y lógico. En 1633, en la Hermandad de los Negros, en su Sermão XIV do Rosário, Antonio Vieira compara los sufrimientos de Cristo al de los esclavos, los mismos oyentes: "En un ingenio vosotros sois imitadores de Cristo Crucificado: porque padecen de un modo muy semejante a lo que el Señor sufrió en la cruz y en toda su pasión. Su cruz fue compuesta de dos maderos, y la de vosotros en un ingenio es de tres. Cristo desnudo, y vosotros desnudos; Cristo sin comer, y vosotros hambrientos; Cristo en todo maltrato y vosotros maltratados en todo" (Bosi 51). En Cultura e opulência do Brasil por suas drogas e minas, el autor en cierto modo reconstruye la historia de las "riquezas do Brasil" a partir de los principios estéticos del Barroco. Afranio Coutinho habla de una influencia poderosa del barroquismo sobre la historia de la colonia portuguesa en América, como una relación en que se confunden los orígenes. En la América portuguesa prima una forma específica de la manifestación del Barroco:

La literatura en el Brasil colonial es literatura barroca, y no clásica, como hasta ahora era regla decir. La literatura nació en Brasil bajo el signo del Barroco, por la mano de los jesuitas. Y fue al genio plástico del Barroco que se debió la implantación del largo proceso de mestizaje, que construye la principal característica de la cultura brasileña, adaptando las formas europeas al nuevo ambiente, a costa 
de la "transculturación" de que habla Fernando Ortiz, conciliando dos mundos -el europeo y el autóctono (Coutinho 113).

De ese modo, el arte literario que se forja en Brasil durante los siglos XVII y XVIII y que se adscribe a la estética barroca, es utilizado como una forma de expresión que se impone sobre el discurso religioso clásico y moralizador que inunda el ethos colonial. El mundo que se refleja en el texto barroco es imagen afiligranada, composición constelar que suma estados del alma y artificios humanos, elaboraciones asimétricas de estilos de vida y simbolismos sensuales, mundos disímiles y semejanzas ocultas. La naturaleza y los habitantes de Brasil han sido, según Candido, el motor para la elaboración de una literatura cargada de imágenes y de una expresión complicada y rica que tiene como consecuencia la transfiguración de la realidad. En este sentido, la obra de Antonil, considerada por el crítico como un escritor "atento a lo real", está envuelta por "una frondosidad hasta cierto punto redentora, que prestó a la tierra bruta estatura de leyenda y contornos de maravilla" (93). La idea de literatura por tanto estaría adscrita a la alegoría de los mundos y de los hechos, al drama de la carne y del espíritu, a la concepción ideológica de la existencia.

El siglo XVIII es, de forma general, un momento de transición política y social de preparación para la independencia. La colonización de la América portuguesa presenta, entonces, un desarrollo con vistas a la fijación de poblaciones en el territorio tras una serie de episodios que progresivamente van definiendo las condiciones de vida en la colonia, al mismo tiempo en que implanta modelos de prosperidad económica, especialmente en lo que se refiere al descubrimiento y explotación de las minas de oro en Minas Gerais. En este marco se inscribe una suerte de organización económica y política que conlleva al cultivo de un ambiente favorable a las creaciones artísticas y culturales que se desarrolla junto a la "creación de la conciencia histórica" en Brasil".

9 La conciencia histórica en Brasil nace, según algunos historiadores, a partir de la instalación de la corte portuguesa en Brasil. Así mismo, la conciencia 
Este sentimiento común, del cual se origina el "orgullo nacional", traducido por los hechos heroicos y la fáustica historia brasileña, la que agrega la instalación del reino de Portugal en la colonia americana, incluye la figura del "brasileño", poblador mestizo de "sangre y alma, el tipo local que el mestizaje y la aculturación fueron desarrollando, plantado en el piso, con la noción de propiedad de la tierra que defendió y preservó y amplió" (Coutinho 123), noción de propiedad de la tierra que tiene como consecuencia la conciencia del "ser brasileño", genera también una lengua diferente, que expresa los temas locales. Aunque se afirme que el Barroco a inicios del siglo XVIII demuestre señales de decadencia, preparando el suelo para nuevas formas y nuevos cánones, instalados en las academias literarias, esta manifestación artística ha sido una necesaria revelación colonial, que se presenta en el siglo XVIII en la obra de Nuno Marques Pereira, Compendio narrativo do peregrino da América em que se tratam de vários discursos espirituais e morais, com muitas advertências e documentos contra os abusos que se acham introduzidos pela malícia diabólica no Estado do Brasil, publicada en 1728.

La obra de Marques Pereira narra el viaje de un supuesto peregrino desde la capitanía de Bahía hacia la capitanía de Minas Gerais, con el propósito de buscar la presencia del demonio en la vida cotidiana de la colonia, que simultáneamente describe las costumbres religiosas del Brasil en el siglo XVII. El Peregrino de América refleja las formas barrocas brasileñas que fluyen en el intersticio moral que son también otras formas múltiples, rostros, diversas estéticas, ejercicios de vida en que otras sociedades, etnias e individualidades conviven. Es cierto que abundan las lecciones morales, dirigidas a negros libres o esclavos, criollos, portugueses, indígenas y mestizos, funcionarios metropolitanos de todo tipo. El manto del contrabarroquismo se extiende por toda la colonia, sin lograr, entretanto, disolver la doble influencia: la prédica de una moral pública que busca la práctica y el ejercicio de una perfección

nacional surgiría en el siglo XVII, con la expulsión de los holandeses del nordeste brasileño, prefigurando la unidad nacional. 
espiritual, contribución de la contrarreforma portuguesa y que comparte espacios con una práctica sensual en el ámbito privado. De ese modo, en el Compendio narrativo se encuentran escenas del cotidiano y detalles sobre las prácticas rituales de los negros e indígenas, hábitos alimenticios, como la función de la moral religiosa frente a las prácticas heréticas.

El cotidiano que la obra de Nuno Marques Pereira describe también es el universo por el cual transita la poesía barroca de Gregorio de Matos. Poeta del Reconcavo baiano, región de Bahia, "noble y opulenta ciudad" (49), apodado "Boca del Infierno", sus poemas satíricos, así como la lírica religiosa y profana expresan el mundo barroco colonial, época de contradicciones y dualismos. Según José Miguel Wisnik, oscilando entre Portugal y Brasil, Gregorio construye sus referencias insertado en un contexto de decadencia tras la progresiva caída del imperio comercial portugués en Oriente, de las restricciones al comercio de Brasil para el provecho de la corona, la crisis financiera de los propietarios de tierras y fabricantes de azúcar, que ven el precio de su producto caer globalmente, cuando entra en escena la competencia de las colonias españolas e inglesas, haciendo nacer otra economía, la del comercio y del crédito (14).

Esta nueva perspectiva colonial trae consigo el surgimiento de una capa de la sociedad que presenta rasgos de una burguesía compuesta en su mayoría por portugueses moradores de Brasil que, provistos de los recursos materiales ponen en duda la nobleza de los hacendados, quienes hasta entonces detentan una situación de prestigio en la colonia. Esta nueva sociedad domina la administración y los tratos financieros de los contratos reales, como la renta fiscal de la colonia y los monopolios, que prosperan amparados por una política determinada en la metrópoli, tornándose en enemigos de los propietarios rurales criollos. Junto al cambio en la política económica, están las nuevas formas de control sobre la colonia, ya que, frente a la debilidad del poder local se fortalecen los gobernadores y funcionarios reales, en la creación de un espacio en que las diferencias y contradicciones constituyen un terreno propicio a la sátira de Gregorio de Matos, plena de tensiones.

Alejado de la descripción simple, Gregorio incorpora, de hecho, en su producción poética, las características de la sociedad y del universo barroco: "el hijo del señor de ingenio encuentra el ingenio en plena crisis"; 
cautelado por los negocios coloniales, "el bachiller, naufragado en el purgatorio", entre la multiplicidad de la vida en la colonia y el "poeta culto que se ve en un medio iletrado", en que la literatura se encuentra bajo la tutela de la iglesia y la academia, representa un modelo que "resulta incómodo para Gregorio de Matos" (15). La sátira del Boca del Infierno es la colonia misma, en que la experiencia del poeta itinerante, vagabundo y crítico, se transforma en arte y noticia, reflejándose en el desconcierto de la máquina del mundo. En ese sentido, Wisnik habla de la contradicción en la obra de Gregorio de Matos, que reside en la dualidad experimentada por el conocimiento de la diferencia entre colonia y metrópoli, así como la distinción entre el acaudalado brasileño reconocido en Portugal y la pérdida de prestigio en la colonia. De este modo, el poeta incorpora simultáneamente la idealización del pasado a la agresión al mulato, presente en muchas obras del siglo XVIII en Brasil: "Un blanco muy encogido,/ un mulato muy osado,/ un blanco todo coitado,/ un canaz todo atrevido;/ el saber muy abatido,/ la ignorancia e ignorante / muy ufana e muy farfante,/ sin pena o contradicción:/ milagros del Brasil son" ("Ao padre Lourenço Ribeiro, homem pardo que foi vigário da Freguesia do Passé", Sátira 45).

Instrumento importante para enfrentarse a las injusticias y a los desafectos, como denuncia de una sociedad plagada de vicios y absurdos, la sátira funciona en contrastiva armonía con el entorno de la colonia. Las dualidades del arte barroco también están presentes en el poeta lírico, muchas veces tejidas sobre explosiones de erotismo: "unión de vientres, un breve temblor de arterias, una confusión de bocas" (294). En lo que concierne a los poemas que contienen aspectos de la sociedad del Recóncavo, Gregorio de Matos parece incluir la múltiple composición étnica y cultural, como se ve en Queixa-se a Bahia por seu bastante procurador, confessando que as culpas, que lhe increpam, não são suas, mas sim dos viciosos moradores que en si alverga: "Contados son los que dan/ a sus esclavos enseñanza,/ y muchos ni de comer,/ sin les perdonar servicio./ $¡ \mathrm{OH}$ ! cuantos y cuantos ha/ de bigote fernandino,/ que hasta en la noche a las esclavas/ piden salarios indignos!" (Preceito 4, 77). Bahía, capital de la colonia portuguesa, es la ciudad más próspera de América en la segunda mitad del siglo XVII: "El gobernador sostenía una especie de corte, capaz de llamar la atención de los curiosos. El lujo era general, y además la máquina -el esclavo- era superabundante" (Romero 51). 
El primer siglo de la colonización de Brasil conoce la supremacía del nordeste, a través de la capitanía de Pernambuco, que gana prestigio en la figura de sus pobladores y en el éxito del cultivo y la explotación de la caña de azúcar, que luego se extenderá por otras regiones del territorio colonial. Desde el siglo XVII hasta mediados del XVIII, la "ciudad de Bahía" es la referencia artística que acompaña la condición sociopolítica. Según Jorge de Sena en sus estudios sobre la cultura brasileña, Gregorio de Matos y Manuel Botelho han sido productos lusobrasileños de la riqueza baiana del siglo XVII: "Manuel Botelho de Oliveira, 'fidalgo do rei', formado en Coimbra donde fue contemporáneo de Gregório y que, de regreso al Brasil, ejerció altos cargos e fue riquísimo (prestaba dinero al propio Estado), es, aun más que él, [Gregorio de Matos] un representante refinado do seiscentismo barroco, ya que o cultismo é a base esencial de su poesía que, profana o religiosa, es un puro ejercicio literario" (411).

En este período, comienzos del siglo XVIII, "las manifestaciones culturales de la Colonia no presentaban cualquier nexo entre sí, pues la vida de los pocos centros urbanos aún no propicia condiciones para socializar el fenómeno literario" (Bosi 53). De este modo, la implantación y fijación de la cultura letrada dependen del grado de desarrollo y poder económico de los centros urbanos en el Brasil colonial, beneficiados por la actividad de explotación de las minas. Según Alfredo Bosi, religiosos, militares y altos funcionarios se reúnen en gremios literarios cuyos contenidos siguen los ejemplos de sus pares portugueses y europeos en general. El crítico señala que en su versión brasileña, las academias representan el cierre del Barroco y el nacimiento de una nueva estética, que privilegia una "cultura humanística viva, extraconventual" en la sociedad colonial brasileña (54).

En Bahia surge la Brasílica dos Esquecidos (1724-1725) y la Brasílica dos Renacidos (1759) y en Rio de Janeiro Academia dos Felizes (17361740) y la Academia de los Selectos (1752). Simultáneamente fiesta religiosa y resultado de la opulencia proporcionada por las minas de oro, "ocurría una mezcla de espectáculo devoto e intención encomiástica /.../ exhibición de carros alegóricos, ópera mitológica, fuegos de artificios e 'folias' de negros por las calles representadas por los seminaristas, a mediados de agosto de 1770, con ocasión de la llegada de la imagen de 
Sant'Ana. Sermones, textos de ópera y poemas entonces escritos fueron compilados bajo el título de Academia dos Felizes a ejemplo del grupo fluminense" (Bosi 57). Esta dependencia de la producción literaria que, en su forma más académica y formal, depende la necesaria riqueza material para desarrollarse, se inscribe en el ámbito del crecimiento de la colonia como productora de oro, configurándose las ciudades bajo las orientaciones de la sociedad europea.

Sin embargo, otras realidades fluyen bajo estas influencias. El gran contingente de esclavos presente en la colonia crea nuevos tipos de cultura que influye profundamente en el cotidiano, sea de las ciudades o de los ingenios. Regido por el cristianismo, el colono en Brasil convive con una suerte de cristianismo familiar, hombres y mujeres en el aislamiento del ingenio, lejos de la vigilancia del obispado y servidos espiritualmente por el padre familiar, quien dispone de una capilla dentro de la hacienda: "la fluidez de la organización eclesiástica habría dejado espacio para la actuación de los sacerdotes del ingenio que gravitaban alrededor de los señores: descuidando el papel del Estado y enfatizando el de las familias en el proceso de la colonización" (Mello e Souza 87).

\section{OPULENCIAS DE LA COLONIA: METÁFORAS DE DOLOR Y RIQUEZAS}

Mientras Gregorio de Matos sintetiza, en su producción poética, la vida cotidiana de las calles, de los conventos y de las oficinas administrativas en Bahía, el padre Antonil busca describir la vida en el ingenio en todas sus instancias, aun en lo que concierne a la vida privada de los propietarios de tierras. Cultura e opulência do Brasil es un texto clave en lo que se refiere a la transición del siglo XVII al XVIII. Obra que por su carácter literariocultural, otorga sentido a las relaciones humanas y sociales en medio al surgimiento de nuevas prácticas de vida social e individual en la colonia. En el Libro I, capítulos X y XI, Antonil enseña cómo deben actuar los miembros de una familia moradora en el ingenio de azúcar. Son orientaciones sobre cómo gobernar la familia y los gastos de la casa y cómo educar a los hijos; "tener los hijos siempre consigo en el ingenio, es criarlos tabaréus, que en las conversaciones no sabrán hablar de otra cosa más que del perro, del caballo y del ganado" (I-X); recibir a los huéspedes, religiosos o seglares: "tener casa separada para huéspedes é grande acierto, porque mejor se recibir 
y con menor estorbo da familia e sin perjuicio del recogimiento que han de guardar las mujeres y hijas y las jóvenes de servicio interior, ocupadas de la cena" (I-XI).

Las orientaciones que en el texto de Cultura e opulencia sirven para tornar más eficiente la producción y la convivencia humana en la colonia, terminan por construir un entramado textual en que metáforas y metonimias operan en el sentido de la lógica comercial y simbólica. En la narrativa dicotómica de Cultura e opulencia, el negro, como pieza, debe estar conscientemente instalado en el proceso de producción no solo del azúcar, sino de todo el escenario del ingenio, como parte de la máquina de la industria del azúcar: "años en que, por la mucha mortalidad de los esclavos, caballos, yeguas y bueyes o por el rendimiento de la caña, no pueden los señores de ingenio llegar a dar satisfacción entera de lo que prometieron" (I- XII). De este modo, la doble lectura sugiere que el autor entiende el esclavo africano como un todo, que debe ser separado en el trabajo esclavo, de acuerdo a sus habilidades y carácter. Sin embargo, es propio del sistema esclavista reconocer el negro africano esclavo como pieza, un ser sin contornos definidos en sus singularidades étnicas. Del mismo modo que considera el cuerpo del esclavo como parte de una máquina productiva, en que sus brazos y sus pies pertenecen al amo y su fuerza física garantiza buenos dividendos, Antonil no olvida los "atributos morales" del producto colonial cuando describe "Do que padece o açúcar desde o seu nascimento na cana, até sair do Brasil": En la narrativa de Cultura e opulencia se encuentra una suerte de humanización del azúcar, en que Antonil habla de las penas y martirios impuestos en el "teatro de los tormentos":

/.../ primeramente hacen pedazos las que plantan y las sepultan así cortadas en la tierra. Mas, volviendo logo casi milagrosamente a resucitar, ¿qué no padecen los que a ve salir con nuevo aliento y vigor? Ya mordidas por varios animales, ya pisadas por bestias, ya derrumbadas por viento, $\mathrm{y}$ al fin descabezadas e cortadas con azadones. Salen del cañaveral amarradas; e, ¡OH!, ¡cuántas veces antes de salir son vendidas! Llévense, así presas, o en los carros a la vista de las otras, hijas de la misma tierra, como los reos, que van amarrados para la cárcel, o para el lugar del suplicio, padeciendo en sí confusión dando a muchos terror /.../ Llegadas a la molienda, ¿con qué fuerza y aprieto, postas entre los ejes, son obligadas a dar cuanto tienen de 
sustancia? ¿Con qué desprecio se lanzan sus cuerpos aplastados y despedazados al mar? ¿Con qué impiedad se queman sin compasión en el bagazo? (III-XII).

La metaforización del azúcar como persona que sufre (que padece dolores y humillaciones), que posee atributos humanos (lágrimas, pies, rostro) y que se esfuerza para al fin tornarse blanco y puro: "sale de esta suerte de purgatorio y de la cárcel, tan albo como inocente" (III-XII), para volver a sufrir martirios en manos de mujeres: "sobre un bajo balcón se entrega a otras mujeres, para que le corten los pies con cuchillos" (III-XII), aproxima a los hornos de la casa de purgar al infierno. Los hornos, con sus bocas "tragadoras de leña", cárcel del fuego y humo perpetuo, viva imagen de los volcanes, "Vesuvios e Etnas y casi dije, del Purgatorio y del Infierno" (III-VIII), contemplan a sus "condenados", los esclavos responsables por la fabricación del pan de azúcar. De ese modo, el negro trabajador debe, en el ingenio, establecer una suerte de autopurgación: "ni faltan cerca de estos hornos sus condenados, que son los esclavos bubentos, y los que tienen corrimientos, obligados a esta penosa asistencia para purgar con sudor violento los humores gálicos que tienen llenos sus cuerpos" (III-VIII).

La cristiandad mal organizada a la que se refiere Antonil también es aplicada a los esclavos negros quienes, obligados a recibir el bautismo antes de dejar África, mayormente no son objeto de la preocupación de los propietarios de ingenios en cuanto a la conversión efectiva. Antonil advierte esta falta religiosa en el Libro I, capítulo IX “Como se há de haver o senhor de engenho com seus escravos". El texto empieza con una suerte de elogio al trabajo del esclavo, como sustento fundamental de la economía de la colonia y de la prosperidad particular del ingenio: "los esclavos son los pies y las manos del ingenio, porque sin ellos no es posible hacer, conservar y aumentar hacienda, ni tener ingenio corriente" y sigue con las descripciones de cada tipo étnico y su aplicabilidad en el negocio del azúcar, clasificándolos por región y grupo étnico.

De ese modo, reconoce sus diferencias anteriores, pues logra distinguir la diversidad de naciones y las diferencias fundamentales entre cada una, diferenciando los ardas de los minas, congos, los de São Tomé, Angola, Cabo Verde, Mozambique. Los más débiles y los más hábiles en el aprendizaje de una ocupación, en ese caso, considera los del Congo "bastante industriosos y buenos no solamente para el servicio de la 
caña, sino para las oficinas y para el manejo de la casa" (Libro I, IX). Sin embargo, estas destrezas no se hacen acompañar de un refinamiento espiritual y lamenta el poco cuidado de algunos propietarios con relación a la salvación de sus esclavos "que los tienen por mucho tiempo en el cañaveral o en el ingenio, sin bautismo; $y$, de los bautizados, muchos no saben qué es su Criador, lo que han de creer, qué ley han de guardar, cómo se han de encomendar a Dios, a qué van los cristianos a la iglesia, por qué adoran la hostia sagrada /.../" (I-IX) y continúa, en enumeración de todo el procedimiento que falta en la práctica religiosa cristiana de los cautivos. No obstante, el autor relaciona el abandono de la enseñanza del sentimiento cristiano entre los esclavos con el desamparo material en que se los mantiene.

La falta de cuidado con relación al cautivo se traduce en la costumbre que el jesuita denuncia: "claro está, que se les no debe negar /.../ dar suficiente alimento, mezinhas en la enfermedad y modo con que decentemente se cubra y vista, /.../ no apareciendo casi desnudo por las calles; en Brasil /.../ para el esclavo son necesarios tres PPP, a saber, palo, pan y paño" (I-IX). La negligencia del amo con relación a sus cautivos puede llegar a comprometer una de las estrategias más utilizadas por los colonos en la manutención del control y sumisión del esclavo que Antonil percibe ser fundamental: "negarles totalmente sus juegos, que son lo único alivio de su cautiverio, es quererlos desconsolados e melancólicos, de poca vida y salud. Por tanto, no les extrañen los señores el criaren sus reyes, cantar e bailar por algunas horas honestamente en algunos días del año, y el alegrarse inocentemente en la tarde después de haber hecho por la mañana sus fiestas de Nossa Senhora do Rosário, de São Benedito" (I-IX).

La mención a Nuestra Señora del Rosario y a San Benedicto son referencias al sincretismo y muestran la capacidad del padre Antonil de captar la sociedad brasileña esclavista. Según la historiadora Laura de Melo e Souza en su ya clásico estudio sobre la religiosidad popular en la colonia portuguesa en América, Antonil sería "más clarividente que muchos historiadores contemporáneos" (93), en lo que concierne a la referencia a San Benedicto como un culto lícito, en la previsión 
de Antonil ${ }^{10}$. San Benedicto, conocido como el Moro, muerto en 1569, descendiente de esclavos etíopes, es el protector de los pueblos de origen africano cuyo culto ha sido prohibido por dos siglos. Los orígenes del catolicismo africano están ligados a una serie de historias que cuentan los primeros contactos de los negros con los santos cristianos. En el caso de la Virgen del Rosario, su devoción se refiere a la batalla de Lepanto en 1571, con la victoria de los cristianos sobre los moros, extendiéndose hacia la costa africana a través de diversas historias.

Una de ellas es el episodio que cuenta su surgimiento de las aguas del mar y la intervención de la ayuda del ritual religioso negro que permitió su rescate. $\mathrm{O}$ aun el negro cautivo que, melancólico por su condición tuvo sus lágrimas transformadas en semillas que sirvieron para la confección de rosarios de la santa. De todos modos, el cristianismo ha utilizado la imagen de la santa para la catequesis de África, relacionándola con el orishá Ifá, oráculo de hombres y dioses y quien posee un collar de semillas de palmeras, asociado al Rosario de Maria. Intrínsecamente ligadas a la coronación de los Reyes Negros, las fiestas del Rosario eran incentivadas por el clero local como forma de mantener en los negros cautivos la salud emocional que reclama Antonil, que ven a sus reyes ser coronados en una fiesta de baile, música y representación (RosaneVolpatto en http://www. rosanevolpatto.trd.br/festanossasenhora).

10 Hasta hoy, São Benedito es festejado en muchas ciudades, como Aparecida (durante nueve días, doscientos mil peregrinos), Paraty, en el litoral de São Paulo o en Serra, ciudad del Espíritu Santo, estado de Brasil. En sus fiestas, se reúnen grupos de tradición popular, entre Moçambiques, Congadas, Marujadas, Catopés y Cabeções. En el desfile de la Caballería de São Benedito participan alrededor de 500 hombres, vestidos de blanco, montando caballos escogidos. Las procesiones que conducen la imagen son acompañadas por los grupos que cantan y danzan sus propias músicas. La realización de la Fiesta de São Benedito -la fiesta del Santo Negro- que acontece también en otros lugares de Brasil, en la segunda semana después de la Pascua, siempre en la Iglesia de Nossa Senhora do Rosário, protectora de los esclavos, implica, como describe el antropólogo Carlos Rodrigues Brandão, "un complejo sistema de cambios de acciones de servicio que envuelve tipos de participantes y modos de participación, tanto en las esferas amplias de relaciones entre la sociedad promotora y la fiesta del santo, cuanto en las esferas de los cambios entre "hermanos" danzantes de Congadas e Moçambiques de ciudades del Valle del Paraíba y de Minas Gerais, los encargados de la hermandad del Rosário y otros agentes responsables por la fiesta" http://www.saopaulo.sp.gov.br/ 
Las fiestas coloniales brasileñas en los siglos XVII y XVIII son también catalizadoras del sentido sincrético de la sociedad brasileña. Celebraciones de alta duración, como es el caso de la fiesta de Nossa Senhora do Rosário, conjugan carnavalización y ritual, regulados tanto por el sentimiento religioso como por la necesidad de reconocimiento de las identidades:

El ritual colectivo del carnaval, comprendida la palabra en su concepto más amplio de sentimiento de euforia y liberación de potencialidades sensibles, tanto abarca el exceso de la propensión profana de quiebre momentáneo y atenuador del compromiso de trabajo y obligaciones en sociedad, cuanto la necesidad de expansión y afirmación de valores de conocimiento menos pragmático, cuales son los de religiosidad y de conciencia místico-cívica (Ávila 260).

De ese modo, la fiesta actúa como un momento-entre, en el cual las relaciones de poder entre colonizador y colonizado, amo y esclavo, dan lugar a una suerte de "salida antropológica" para la interacción de diferentes componentes étnicos en la misma sociedad, "colocando en el mismo palco a actores de habla y máscaras diversas, como el colono de origen portugués, el trabajador negro y el indígena, al lado del fortuito elemento extranjero, la fiesta colonial brasileña /.../ un espacio de discurso de la identidad cultural" (Ávila 261).

En las colonias americanas, donde la cultura de la caña de azúcar domina la economía, los esclavos negros constituyen una fuerte presencia. Esta conjunción azúcar y esclavo conforma en el espacio americano un territorio ensombrecido por relaciones radicalmente diferenciadas, minando las interpretaciones intersticiales que caracterizan las relaciones interétnicas. En el mismo dinamismo colonial que crea la necesidad del castigo hacia el negro en el cañaveral, se instala la sociedad colonial que solo encuentra su específica relación en las manifestaciones culturales y religiosas. El trato del esclavo como "cosa" o "pieza" revela la necesidad de inventar nuevas identidades para el otro, generando una desigualdad.

Sin embargo, la convivencia inevitable entre el colonizador y las diversas etnias de América promueve el desarrollo de las prácticas sincréticas y de mestizaje. En el mantenimiento del sistema colonial, los europeos crean una cierta legitimidad para la cultura negra. Arrancados de sus orígenes africanos, los esclavos negros no pueden recrear en América 
el ambiente ecológico en que se habían constituido sus divinidades. Por lo tanto, anclados en el sistema mítico originario, lo recompusieron en el nuevo medio ${ }^{11}$ : "La esclavitud destruyó la organización doméstica y política, pero dejó subsistir las religiones africanas, que continúan hasta hoy. La religión daomeana, de los voudous, en el Marañón. Y la religión yoruba, de los orishas de Bahia, en Pernambuco, Alagoas, bajo los nombres de Tambor de Mina, candomblés o shangós" (Bastide 73).

Las religiones africanas vividas por los esclavos negros en América se tornan, así, diferentes de aquellas de sus antepasados. Es común asociar el sincretismo religioso en Brasil a partir de las relaciones entre las religiones africanas y el catolicismo. No obstante, otro sincretismo se dibuja en el espacio afrobrasileño, en que las religiones africanas se desconstruyen, amalgaman, diluyen unas en las otras, con el fin de formar otras semejanzas. El sincretismo africano se reconfigura, por lo tanto, a la luz de las necesidades y de las nuevas realidades y los múltiples grupos étnicos, o nações. Los Gegês, Nagôs, Yorubás, Malês, y tantos otros elaboran el sincretismo afro-católico. En el imaginario de la religiosidad africana en el universo colonial, ya no hay cabida para pedir fecundidad a las mujeres, pues ellas generarán hijos cautivos. No hay razón, asimismo, para solicitar a los dioses buenas cosechas en una agricultura que beneficia a los blancos, que se orienta hacia el comercio externo y no a su subsistencia. Más vale pedirles la sequía, las epidemias destructoras de las plantaciones, pues la cosecha abundante se traduce en más trabajo, más fatiga y más miseria para el esclavo.

La primera selección de plegarias operada en el seno de la religión africana coloca a un lado las divinidades protectoras de la agricultura, valorizando las de la guerra (Ogum), de la justicia (Xangô), de la venganza (Exu). El natural predominio de estos dioses empieza, en la colonia mestiza, a entronizarse como dioses de una clase oprimida. Sin embargo, el catolicismo de origen europeo continúa, en la colonia, mezclándose

${ }^{11}$ En Cuba, Haití y Brasil, los cultos formales de los negros fueron combatidos implacablemente, tolerándose las manifestaciones culturales de las prácticas médicas, que, por medio de los sacerdotes, servían también para regular la comunidad contenida en las senzalas brasileñas o en los barracones caribeños, asumiendo el papel de regulador social. 
con elementos extraños a él, múltiples como las mismas religiones transmigradas, las africanas, que aún hoy cargan con la sensación de que parte del conocimiento religioso se perdió en el traslado desde África hacia Brasil "y de que en algún lugar existe una verdad perdida, un conocimiento olvidado, una revelación oculta" (Prandi 72).

La religión es solo un elemento del mestizaje en la colonia portuguesa en América. El negro africano pertenece a una suerte de civilización creada en los trópicos, la "civilización de la caña de azúcar". Roger Bastide y Gilberto Freyre la sitúan como la base de una brasilidad que se nota en los cantos, la risa, las danzas, en el ritmo de los tambores, en el modo de caminar. Freyre refiere a una inclusión africana en el vocabulario y en las formas suavizadas del portugués hablado en Brasil: "en vez de dura y seca, crujiendo en el esfuerzo por adaptarse a condiciones completamente extrañas, la cultura europea se puso en contacto con la indígena, suavizada por el óleo cálido de la mediación africana" (Freyre 75). No obstante, la "mediación africana" fundamenta no solo las relaciones intrínsecas al mestizaje y sus desdoblamientos, sino aquellas fortalecidas por la expectativa de la generación de riquezas materiales que se originan en el seno del sistema esclavista. Para ello, la imaginación occidental colonizadora ha creado estereotipos contradictorios respecto a la "naturaleza del negro africano".

\section{BIBLIOGRAFÍA}

Antonil, André João. "Cultura y opulencia do Brasil”. http://www.dominiopublico.gov.br , mayo2008,http://www.dominiopublico.gov.br/pesquisa/DetalheObraForm.do?select action $=\&$ co_obra $=1737$

Ávila, Affonso. "Festa barroca: ideologia e estrutura". América Latina: Palavra, Literatura e Cultura. Vol. 1, A situação colonial. Org. Ana Pizarro. Campinas: Editora da Unicamp, 1993.

Benci, Jorge S. J. Economia cristã dos senhores no governo dos escravos (1700), São Paulo: Grijalbo, 1977.

Bastide, Roger. Brasil, terra de contrastes. São Paulo: Difel, 1976.

Bosi, Alfredo. Historia concisa da literatura brasileira. São Paulo, Editora Cultrix, 1985.

Buarque de Holanda. Raízes do Brasil. São Paulo: Compañía das Letras, 1996.

Candido, Antonio. Literatura e sociedade. São Paulo: Companhia Editora Nacional, 1985.

Castro Henriques, Isabel. O pássaro do mel. Lisboa: Edições Colibrí, 2003. 
Coutinho, Afranio. Introdução à literatura no Brasil. Rio de Janeiro: Editora Civilização Brasileira, 1976.

Dimas, Antonio. “Antonil, a Cana e o Negro”. Seção Textos, n. 15, www.usp.br set.-nov./1992. www.usp.br/revistausp/autores.textos/textos.php

Freitas, Decio. Palmares. A guerra dos esclavos. Porto Alegre: Mercado Aberto, 1984.

Freyre, Gilberto. Casa Grande \& Senzala. Caracas: Biblioteca Ayacucho, s/d.

Marina de Mello e Souza. "Catolicismo negro no Brasil: santos e minkisi, uma reflexão sobre miscegenação cultural”. Afro-Asia 28 (2002): 125-146.

Matos, Gregorio de. Poemas escolhidos. São Paulo: Editora Cultrix, s.d.

Nunes, Clicie. "Curiosidades coloniales en letra y trazo: una proyección mundializadora". Revista Chilena de Literatura 70 (2007): 109-133.

Pereira, Nuno Marques. Compêndio narrativo do peregrino da América (1728). Vol 2. Rio de Janeiro: Publicações da Academia Brasileira, 1939.

Prandi, Reginaldo "As religioes negras no Brasil. Para uma sociologia dos cultos afro-brasileiros". Revista USP 28 (1996): 64-83.

Romero, Silvio. Ensayos Literarios. Selección, prólogo y notas de Antonio Candido. Caracas: Biblioteca Ayacucho, s/d

Sena, Jorge de. Estudos de cultura e literatura brasileira. Lisboa: Edições 70, 1988.

Taunay, Affonso D'Escragnolle. http://www.dominiopublico.gov.br, mayo2008,http://www. dominiopublico.gov.br/pesquisa/DetalheObraForm.do?select_action $=\&$ co_obra $=1737$ 